\title{
TOWARDS A POSTMODERN METONYMY OF FORMAL LIBERATION/EMPOWERMENT: ANA CASTILLO'S THE MIXQUIAHUALA LETTERS
}

Monica GOT ${ }^{1}$

\begin{abstract}
By addressing the peculiarities and formal inventiveness of Ana Castillo's novel The Mixquiahuala Letters, the paper identifies and categorizes the elements of identity that generate the metaphysical construction of a bicephalous feminine/feminist experience-a permanent fluidity of the ethos, a profound alterity of the receptive act, and a radical, disruptive participatory courage. While examining how identity (re)construction can resonate, metonymically, in the actual scriptural arrangement of the novel's text, the paper focuses on the study of the relationship between the formal, textual, and semiotic-receptive representation of the idea of emancipation, through Ana Castillo's explicit auctorial intentionality.
\end{abstract}

Keywords: fluidity, radical authorship, Chicana literature, female emancipation, auctorial intentionality.

DOI: $10.24818 / \mathrm{SYN} / 2021 / 17 / 2.05$

\section{Introduction}

At the beginning of the 1990s, seminal Chicana writer Ana Castillo found herself in a strange position, culturally. She had achieved popular success and was resting comfortably on the pedestal of commercial triumph, alongside Sandra Cisneros and Denise Chávez. She was at the vanguard of Chicana/o literature, and undoubtedly considered an important figure in the American canon, but she had not coagulated the undisputed covenant of academia. Or, more adequately, never expected it (Spurgeon, 2004: 15). This bit of information is all the more interesting since Castillo is set apart from numerous other Chicana writers by the fact that she is a theorist of Chicana literature, as well. This will become relevant as we advance in our enunciation of Castillo's discourse.

I argue that the apparent fragility and inferiority typically attributed to Chicana characters by the retrograde patterns of the male-controlled status quo end up assigning the former a modular type of individuality. Fictional Chicanas are thus transformed into permeable canvases, all the more interesting to populate with the readers' own intellectualized notions of 'masculinity' and strength, which only

\footnotetext{
${ }^{1}$ Monica Got, Bucharest University of Economic Studies, monica.got@rei.ase.ro
} 
comes to confirm their resilience and malleability in the face of adversity, which they counter with an ever-renewed capacity towards spiritual reinvention.

As such, in a rather counterintuitive way, exposure to trauma becomes a means of empowerment, provided that traumatic experiences lead to a recalibration of one's sense of self and a complete alteration of the perception that the former victim - in her freshly acquired position as a survivor - will have on both the world and the part that she is now supposed to play in it. Hence, fictional Chicanas - mirroring and evoking countless real-life cases having occurred within the Chicana community - graduate to a whole new level of insight and self-knowledge, forcing the boundaries of a once restrictive, oppressive and traumatizing ethos, by refusing any and all self-victimization or symbolic marginalization.

Regardless of whether they are portrayed as victims of rape, domestic abuse, gang violence or just old-school misogyny, socioeconomic exclusion, and gender discrimination, many a time fictional Chicanas manage to rewrite trauma as a journey of becoming. By looking at the dynamic of female epistolary interaction and auctorial intentionality in Ana Castillo's acclaimed novel The Mixquiahuala Letters, the present paper aims at redefining traumatic experiences as spaces of change and reinvention, arguing that many Chicana fictional characters manage to endure in the readers' collective memory not in spite of (being subject to) trauma, but perhaps even because of (overcoming) it, due to the surprising metamorphoses of which they prove themselves capable, both within the narrative universe and outside of it - as imaginary exponents of a collective consciousness that I have theorized in previous research as 'traumatic identity.'

It is self-evident that the primary discursive concern of Chicana fiction and theory is "the integrity and authenticity of the ethnic subject" (Carson, 2004: 109), which is denotated as mestiza, a decidedly new, privileged, genetic species of the Frontera, the offspring of centuries of colonization and cultural intermixing. The mestiza is theorized by Anzaldúa as

... the confluence of two or more genetic streams, with chromosomes constantly "crossing over," resulting [not] in an inferior being, [but] a mutable, more malleable progeny with a rich gene pool. From this racial, ideological, cultural and biological cross-pollination, an 'alien' consciousness is presently in the making-a new mestiza consciousness, una conciencia de mujer. It is a consciousness of the Borderlands. (Anzaldúa, 1987: 99)

The trauma induced by centuries of oppression forced the nascent Chicana literature to gravitate towards a discourse of identity-shaping, amidst power struggles and individual issues, at the center of the clash between the dominant society and marginal opposition. Thus, what constitutes the peculiarity of this literature is the means by which it allowed its exponents to produce trickle-down effects of cultural composition. Historically, it demonstrated an appetence and a preoccupation towards an ever-increasing variance of occupied loci in each character's execution of destiny, and by that we refer to the necessary Deleuzian 
positioning, here understood as fragmentation of metaphysical posture, both in terms of philosophical action and social perception. This creates, all through Castillo's work, a diorama that extrapolates and illuminates identity constructs, a "virtual catalog of the subjectivities, often in opposition to one another, [across] Chicana communities". (Delgadillo, 1998: 893)

And yet, Castillo the theorist seems at times to be in direct conflict with Castillo the novelist. In her center-point critical study, Massacre of the Dreamers, she concedes that Chicana writing is compelled to undergo numerous tribulations before ideation, which have a multiplying effect on the identity variance of subjective temperaments (i.e., the ease with which one can pinpoint the fragmentation of the cultural patina), thus heterogenizing the instances of Chicana identity. However, Castillo claims that this identity can still be pinpointed and asserted as "Mexic Amerindian". (Castillo 1994: 12)

Therefore, there is an interesting incongruity between the performativity of Castillo's shaping of her subjects in fiction and the manner in which she chooses to tackle the outer layer and internal framework of her adjacent scholarship. In other words, an inner struggle between her theory and her art takes place. Although she yearns for a cosmic origin of her cultural essence, claiming that "as Mexic Amerindians, we must find a clue as to who we are and from whom we descend, [and] become akin to archeologists" (Castillo 1986: 6), the trademarks of her postmodern works of fiction are exactly the elements that subdue precision and let ambiguity guide their own performative effectiveness, namely the interrogations of one's existential footprints (or beingprints), the secrets of the present's intangibility, and other quests to finding oneself.

This underlying and constant quest for an essence harkens back to the core of a structuralist approach. Derrida coined the notion "centered structure", which we could very well apply to her theoretical enterprise, inasmuch as "one perhaps could say that the movement of any archeology, like that of any eschatology, is an accomplice of this reduction of the structurality of structure and always attempts to conceive of structure on the basis of a full presence which is beyond". (Castillo 1986: 279) The much-touted Anglo perspective emerges here undisturbed, as the center-based epistemology it envelops, and we can safely assert that, perchance shockingly, Castillo forgets to challenge it, and instead replicates it with nonchalant fervor.

\section{Resistance, Ideology, and the Power Dynamic}

To clarify this dilemma, we should first try to access several characterizations of the Chicana/o subject by renowned theoreticians in the field. In his book, The New World Border: Prophecies, Poems, and Loqueras for the End of the Century, by subsuming the subject to the abovementioned notion of mestiza, Guillermo GómezPeña argues that the artist who embraces hybridity is a "cross-cultural diplomat, ...

SYNERGY volume 17, no. 2/2021 
an intellectual coyote (smuggler of ideas) or a media pirate. At other times, s/he assumes the role of nomadic chronicler, intercultural translator, or political trickster," but most importantly he or she must "find the outer limits of his/her culture and cross them". (Gómez-Peña, 1996: 12)

On a more ideologically referential note, and appealing to Gramscian sensibilities, Chela Sandoval posits that subjects are having a hard time liberating themselves from dominant poles of power: "All social orders hierarchically organized into relations of domination and subordination create particular subject positions [which] once self-consciously recognized by their inhabitants, can become transfigured into effective sites of resistance to an oppressive ordering of power relations". (Sandoval 2000: 55)

Hence, there can be no resistance without ideology. Power relations become ascribed to a certain Althusserian dynamic of subjugation and elasticity of agency. The space that they progressively create for their contesting self works as a hybrid consciousness that radiates towards the edges and pushes against the official confines of the margin. The schizoid manner in which an artist can dissociate this new form of consciousness is not unlike a permit for trespassing, an official act that allows for illegal (or, at the very least, irregular, nonconformist) behavior - a tacit pact of ontic shrewdness. A resistance, but one exercised from the inside of the machine - as if there were rules able to dictate the necessity to be swallowed by the Leviathan of patriarchy in order to have a chance at poking its bowels.

Castillo's characters are born hybrids, knowing nothing else besides this hybridity of consciousness. They exert perpetual inferentiality with regard to their subjugated status. Enforcing this transference beyond their differential consciousness, they can only imagine their existence as subjugated border crossers. Like a metronome, they confine their acts and impulses to the to-and-fro between transcultural fronteras places devoid of a center.

The raison d'etre of Chicana/o identity is eternal fluidity. Its ethos belongs to the unlabeled, when any label is perceived and felt as an act of oppressive abuse and dislocation. This narrative ideology of the eternal other engenders discursive articulations that posit and enforce Foucauldian "motionless bases", parchments of forgotten distances, husks of characterization that subjects must abandon in name and practice in order for them to evolve into an "alter-ideology". As Ramón Saldívar elegantly puts it:

Great art distances ideology by the way in which, endowing ideology with figurative and narrative articulations, the text frees its ideological content to demonstrate the contradictions within which ideologies are created. Great art is thus speculative in the most fundamental of senses: it allows us to see. (Saldívar, 1994: 17)

\footnotetext{
${ }^{2}$ A term often used by Michel Foucault in his 1972 book, The Archeology of Knowledge. It denotes the impulse of the interstitial, the coalescence of the periphery.
} 
After evaluating these different but centrifugal takes on the means by which the Chicana/o individual can imagine a relationship to their conditions of existence, as per the transfiguration of said individual upon fictional instances of physical and metaphysical conditions, a distinct flicker of expository answers might unravel towards expounding the aforementioned dilemma concerning the ambivalence of Castillo's approach towards her narratology.

Although, at first sight, one could mistake the duality of takes concerning identity construction for incongruity and something of a double standard, in the light of the few refreshers above, the only logical conclusion must allow for a natural coexistence and even ontological superimposition between narrative and implicit fluidity, on one hand, and the concrete search for the theoretical essence, on the other. They are by no means mutually exclusive, as one might initially believe.

For instance, at the very beginning of The Mixquiahuala Letters, Castillo makes the bold - and unmistakably postmodern - choice of switching interlocution towards the fourth wall and writes: "Dear reader: It is the author's duty to alert the reader that this is not a book to be read in the usual sequence. All letters are numbered to aid in following any one of the author's proposed options". (Castillo, 1986: 9) She then proceeds to presenting her readers with three possible paths to be followed in their appraisal of the novel: the conformist, the cynical, and the quixotic. This instantly calls for a de-crystallization of the one of the most traditional elements of narration, the very cornerstone of novel writing - the auctorial imperative.

Right from the start, the reader realizes that her revisionist agenda is entirely serious - it not only states the new rules without circumventions, but also carries forth a weapon that breaks the blood-brain barrier of conformity and expectation. She reveals herself as a new form of dictator, one that no longer restricts, but retraces and liberates. An opener, and not a closer, by means of concurrently establishing and twisting all traditional authors into the rigid conveyors of form into which history has turned them. The chronological order is overcome by combinatory possibility. It is a limited possibility, of course, for Teresa's destiny, but what matters is that said destiny can at least be something different from the traditionally dictated norm, also known as the patriarchy.

The symbolically deconstructed order thus constitutes the character's representation of the search for selfhood, a self in crisis that could find no conventional path towards crafting an identity. Teresa's disjunction from chronology and narrative convention is a staple of the cited notion of alterideology, one that prioritizes free will and otherness, a bona-fide empowerment of radical otherness, within its connotative relationship to the author's repudiation of her own authority.

A Goddess sacrificing her superpowers in a final gesture that endows her subjects (sic) with freedom of choice - this quantic infinity of layers is crucial to Castillo's 
fiction, but it runs the risk of turning the subject into a nonunitary structure. Ethereally, in its quest to thwart its formal shackles, it also escapes complexity, since the general structure of the novel forces the reader to miss out on all other variances, unless embarking upon the daunting task of taking each and every one of the identity-generating paths. Moreover, the central idea of otherness succumbs to the imperative of the relational; any and all identities can only be relational here, ever depending on the rapport one enacts vis-à-vis its differential consciousnesses. As Tanya Long Bennett postulates,

... by using the epistolary novel ..., by developing tension through language and metaphor, and by manipulating form to show the nature of Teresa's fragmentation, Castillo places readers-and Teresa-somewhere between a perspective that acknowledges ideology and one that rejects ideological dominance. This fluctuation reflects the impossibility of taking any permanent position and foregrounds the resulting fragmentation of Teresa's self. (Long Bennett, 1996: 470)

\section{Fractured Identities at the Intersection of Literary Catharsis and Real-Life Trauma}

The process of molding one's identity is thus simultaneously formal and semiotic. It becomes apparent exclusively in relationship to dominant ideology, but in doing so, transcends it and explores the ontological beyond, as if the construction of the self vibrates at the intersection between monopolistic authority and ascribed outlandishness, between the rigidity of the conventional and the freedom of the alien, a mechanism exuding the dualistic perception of threat and always resulting in something lost (subverted) and something gained (established). The trauma of the initially splintered but subsequently fractured subject is perhaps agonizingly apparent in the letters in which Teresa chooses to talk about both her Mexican heritage and feelings of alienation. In Letter 19, she writes, "Mexico. Melancholy, profoundly right and wrong, it embraces as it strangulates" (Castillo 1986: 59).

The main peculiarity of Castillo's connotation of traumatic experiences seems to be this very duality of the torn figure. Subjects are channeled by society towards an inevitable clash with the self, one that is both metaphysical as it is social. This tragic inescapability of the Borderlands permeates all the bricks with which identity is constructed, at any given time. In Letter 21 , we can see how, to her Mexican Spanish trainer, Teresa bears a resemblance to

the daughter of a migrant worker or a laborer in the North (which of course, [she] was), [although she] was nothing so close to godliness as fair-skinned or wealthy or even a simple gringa with a birthright ticket to upward mobility in the land paved with gold, but the daughter of someone like him, except that he'd made the wade to the other side (Castillo 1986: 20).

SYNERGY volume 17, no. $2 / 2021$ 
Consequently, Teresa understands that, in crafting one's self, one must first and foremost negotiate terms with $a$ society, one that is currently solely defined by the ideology it seems to adhere to, one that confines, hushes, and relegates her to a version as simple as she is ill-equipped to comprehend. Her struggle with a version of Catholicism with which she was instilled since childhood is evident in the following letter to Alicia:

Do you know the smell of a church? Not a storefront, praise the Lord, hallelujah church, or a modest frame building with a simple steeple projecting to the all heavens, but a CATHEDRAL, with doors the height of two very tall men and so heavy that when you pull one open to enter you feel as small as you are destined. You were never led by the hand as a little girl by a godmother, or tugged by the ear by a nun whose dogmatic instruction initiated you into humility, which is quite different from baptism when you were anointed with water as a squirming baby in the event that you should die and never see God face-to-face because you had not been cleansed of the sin of your parents' copulation (Castillo 1986: 24).

It is by picking apart every facet of this socially inducted dogmatism that their picaresque adventures find their revolt-infused backbone-starting with the restriction of feminine travel, very much ingrained with that time's Mexican society. In a manner that echoes a legislation of countries more generally perceived as conservative nowadays-similar, for instance, to applying sharia law in authoritarian Muslim countries-, the Mexican Catholicism of those times considered women traveling unaccompanied something to warrant at least some degree of frowning upon. Although (and perhaps, because) both women are familiar with this fact, they (decide to) experience it firsthand.

Here, the picaresque is fully infused with revolutionary ideology ever since the beginning. Every facet of the patriarchal guidelines is taken apart one after the other, by means of life-affirming actions meant to either defy or ignore them. Adultery and chastity are dismantled by Alicia, who has multiple lovers across the timespan of the novel. Similarly, Catholic piousness is infringed upon when Teresa, although married, decides to have an abortion. Their relationship to men and, more importantly, to Man, are dissected by each letter, with every gesture standing thorough examination.

A particularly striking episode is the one involving Ponce, the engineer who used a form of perceived liberation of the woman, within the confines of malicious rhetoric, much to Teresa's disappointment, in order to simply get into bed with her. In forcing her to admit that he was correct in assuming she was a "liberal woman," he in fact ascribes her the label of "liberated woman," whose meaning becomes binary depending on the discursive genre. In Mexico, this 'liberation' implied a sexual nondiscrimination of partners and subsequent promiscuity, and not at all the

SYNERGY volume 17, no. $2 / 2021$ 
freedom of choice that the unabridged feminism in America struggled to instill in women's minds.

The patriarchal reflex is to blindly (and hastily) consider liberation no more than an inclusive act, even though Teresa rages with despair when she states that liberation represents the freedom of exerting exclusive power in equal measure, as she writes, in reference to sex, that "it also means that [she] may choose not to do it, with anyone, ever" (Castillo 1986: 73). But alas, this remark is laid down post festum, as a mere reaction to what had already occurred, and could be interpreted as simmering frustration at a botched experience of empowerment.

A metaphysical Frontera is slowly becoming apparent here, as the two female characters are unable to secure a social stability of legitimate purpose. Their niche is elusive in the United States, where the illusion of the American dream is the weapon of choice for many crooked or indifferent lovers that use them as fleshed placeholders. Surprisingly to them, the situation is even worse in Mexico, where gringas are besmirched by the stereotype of the liberated woman, a misused and ill-intended appropriation of the term that paves the way for generalized undertones of sexual accessibility. In the symbolic words of critic Maria Oliver-Rotger, "even in the country of their inherited origin and in spite of the color of their skin, their blue jeans and their accent made them suspicious" (Oliver-Rotger, 2003: 263).

\section{The Construction of the Self as Perpetual Struggle}

But, as Anzaldúa herself puts it, these "mental and emotional states of perplexity [and the] internal strife [resulting in] insecurity and indecisiveness" (Anzaldúa, 1987: 100) are normal processes of identity construction, and thus of the shaping of an authentic "free choice". Ultimately, this struggle is perhaps a crucial fragment of the very self they seek.

For Teresa, reassessing the events of their travels is an act of revenge against a new kind of Althusserian interpellation ${ }^{3}$ : in writing, she finds a medium that bestows her with agency. It is a binomial oscillation between deconstruction and construction, like a pendulum between the swaths of oppressive ideologies thrown at her by means of her serialized encounters, vis-à-vis which she feels the earthy urge of taking each apart one by one, like thorny roses picked from a bouquet, subsequently sliding into an existence of the perpetual fight against. But, in time, and with each layer of trauma adding up to her character, this creative practice emerges as a miraculous and most likely unpreventable force of identity construction: an edifice of the self through productive and laborious pain.

\footnotetext{
${ }^{3}$ The process by which the working class is manipulated into accepting the ideology of the dominant one.
} 
As throbbing with agony as the return to her husband in New York was, and as tempted as we might be to label this gesture a form of defeat - which she herself does at one point, when she says, "I was the deserter, giving up Woman's Quest for Freedom and Self Determination" (Castillo 1986: 31) -, this confession only adds to the power of her self-fashioning. Metaphorically, such an act of admission is similar to the isolation of a tumor before surgery - except that, for Teresa, the tumor is her banner, an object she draws strength from, in reshaping, recalculating, and redirecting her reality.

Every gesture is broken down to its most minuscule degree, every defining structure of eventuality is atomized to its lowest possible denominator, because for the mestiza, the being must be in a constant state of awareness, of actuality, a convergent and perpetual motion through creative consciousness, an endless series of narrative gestures converging in each unitary aspect of an individual's Heideggerian paradigm just to be detonated again. Just like a piñata, the self must be violently beaten and destroyed before the praxeological reward can emerge.

Anzaldúa reflects on this theme in Borderlands, and we can find an instantiation of her theories in the depiction of events in Castillo's novels. In Borderlands, she refers to the mestiza in the following terms:

[S] he can't hold concepts or ideas in rigid boundaries ... La mestiza constantly has to shift out of habitual formations; from convergent thinking, analytical reasoning that tends to use rationality to move toward a single goal (a Western mode), to divergent thinking, characterized by movement away from set patterns and goals and toward a more whole perspective, one that includes rather than excludes. (Anzaldúa, 1987: 101)

In fact, Teresa and Alicia do exactly that. By means of their 'reflectionism' - as they establish a virtual mirror in refusing to remain silent - , they violate dominant taboos and push back against the ruling ideology. Here, it is important to remember that this adversarial credo is twofold, or perhaps rather dual-layered. The characters themselves effect radical change by always being either less-than or more-than, never according to local or general social expectations. The implicit argument's strength also derives from the fact that the two women have wildly dissimilar temperaments, an imposed diversity that proactively provides a shielding aura against ulterior, ill-intended criticism (from a critic that could have, for instance, mentioned a unilateral tackling of feminist prose).

\section{Conclusion}

From an auctorial point of view, Castillo refuses the current standard (subsuming it to a classist, sexist, racist order), and finds ways to channel a powerful flux of radical choices that melt away the glue between the hegemony and the status-quo.

SYNERGY volume 17, no. 2/2021 
Within the idea-related experience of a novel (and fiction, to a lesser degree), she defies convention and expectation by allowing the reader to take a central position, depriving the author's historically patriarchal figure of the possibility to exert his dominant and dominating framework upon any reading of Chicana prose. Castillo's postmodern disruption of the privileges of the center shifts the entire experience towards a no-strings-attached participatory subjectivity, in line with the movement's politically revolutionary discourse.

The aforementioned technique is not new, but Castillo's arcana conjures an entire new layer of hermeneutics, for it shows the social relevance of that interdependence. At the time when the book first came out, this inherent and primordial marriage of form and meaning constituted a powerful new weapon in the fight against inequality, an unmasking and the subsequent disentanglement of the etymological bond between author and authority. Thus, existence translates as the act of perpetual becoming, a constant rebellion against social (and ultimately epistemological) stagnation. As critic Alvina Quintana asserts,

[T]he Chicana defies authority in order to break away from the stagnant traditions and ideals that smother and suppress female desire ... Ultimately, the text can be read as a revolt against order which eloquently illustrates why it is essential for feminists to expose and thereby destroy the power of any outside or foreign 'authority' by creating a space for themselves. (Quintana, 1994: 83)

\section{References and bibliography}

Anzaldúa, G. E. 1987. Borderlands/La Frontera: The New Mestiza, San Francisco: Aunt Lute Books.

Carson, B. D. 2004. "The Chicana Subject in Ana Castillo's Fiction and the Discursive Zone of Chicana/o Theory", in Bilingual Review / La Revista Bilingüe, 28(2), Bilingual Press: 109-126.

Castillo, A. 1986. The Mixquiahuala Letters, Tempe: Bilingual Press.

Castillo, A. 1994. Massacre of the Dreamers: Essays on Xicanisma, New York: Penguin.

Delgadillo, T. 1998. "Forms of Chicana Feminist Resistance: Hybrid Spirituality in Ana Castillo's So Far from God", in Modern Fiction Studies, 44(4): 888-916.

Foucault, M., Sheridan, A. 1972. The Archaeology of Knowledge, New York: Pantheon Books.

Gómez-Peña, G. 1996. The New World Border: Prophecies, Poems, and Loqueras for the End of the Century, San Francisco: City Lights.

Long Bennett, T. 1996. "No Country to Call Home: Epistolary Mediation in Ana Castillo's The Mixquiahuala Letters", in Style, 30: 462-78.

Oliver-Rotger, M. A. 2003. Battlegrounds and Crossroads. Social and Imaginary Space in Writings by Chicanas, Amsterdam: Rodopi.

SYNERGY volume 17, no. $2 / 2021$ 
Quintana, A. E. 1994. “Ana Castillo's The Mixquiahuala Letters: The Novelist as Ethnographer", in Calderón H. and J. D. Saldívar. (eds.), Criticism in the Borderlands: Studies in Chicano Literature, Culture, and Ideology, Durham: Duke University Press: 72-83.

Saldívar, R. 1994. "Narrative, Ideology, and the Reconstruction of American Literary History", in Criticism in the Borderlands: Studies in Chicano Literature, Culture, and Ideology, Durham: Duke University Press: 11-20.

Sandoval, C. 2000. Methodology of the Oppressed, Minneapolis: University of Minnesota Press.

Spurgeon, S. L. 2004. Ana Castillo. Western Writers Series, no. 163, Boise: Boise State University.

\section{The author}

Dr. Monica Got is a lecturer with the Department of Modern Languages and Business Communication at the Bucharest University of Economic Studies, where she teaches Business Communication in English. In 2014-2015, she was a junior Fulbright scholar to the U.S. with the Chicano/a Studies Department at the University of California, Santa Barbara. She holds a doctoral degree in Literary and Cultural Studies from the University of Bucharest, with a dissertation titled "Crossing Borders, Merging Homelands. Traumatic Identities in Contemporary Chicana Fiction." Her experience abroad includes a master's program in Paris at the Universite Paris Est-Créteil and a school year teaching English in Catalonia, with a European Commission-funded project. Dr. Got delivered talks at international conferences and published extensively on such issues as hybrid identity, cultural trauma, transnationalism, acculturation, border theory, and collective memory. 